JKKP : Jurnal Kesejahteraan Keluarga dan Pendidikan

http://doi.org/10.21009/JKKP

DOI: doi.org/10.21009/JKKP.062.01

E-ISSN : 2597-4521

\title{
GAMBARAN DUKUNGAN SOSIAL DARI GURU YANG DIRASAKAN OLEH SISWA SMA "X"
}

\author{
Anisah Aninditya Rahmaputri ${ }^{1, a)}$, Dianti Endang Kusumawardhani ${ }^{1, b)}$ \\ a)anisah.putri19@gmail.com, b)dianti.kusumawardhani@ui.ac.id \\ 1)Fakultas Psikologi Universitas Indonesia \\ Jl. Lkr. Kampus Raya Jl. Mawar No.5 3 8, Pondok Cina, Kecamatan Beji, Kota Depok, Jawa Barat \\ 16424, Telp (021) 7270004 fax (021)786 3526, fpsiui@ui.ac.id
}

\begin{abstract}
Abstrak
Guru memiliki peran penting dalam mendidik siswa dengan baik. Salah satu cara yang dapat guru lakukan untuk dapat meningkatkan motivasi serta keaktivan siswa di sekolah adalah dengan memberikan dukungan sosial kepada siswa. Penelitian ini bertujuan untuk mencari tahu gambaran dukungan sosial dari guru yang dirasakan oleh siswa SMA "X" di Tangerang Selatan. Metode penelitian berupa penelitian kualitatif deskriptif dengan teknik pengambilan data melalui focus group discussion dan wawancara terstruktur. Hasil pengambilan data menunjukkan bahwa gambaran dukungan sosial dari guru yang dirasakan oleh siswa SMA " $X$ " cukup memuaskan bagi siswa dari beberapa guru tapi belum semua, sehingga masih dapat ditingkatkan lagi. Hal ini dikarenakan belum semua guru dianggap sudah bagus dalam memberikan dukungan sosial kepada siswa. Total guru yang berjumlah 17 orang untuk siswa sebanyak 67 orang seharusnya dapat ditingkatkan dalam kemampuan komunikasi sehingga mampu memberikan dukungan sosial kepada siswa dengan lebih baik lagi.
\end{abstract}

Kata Kunci : Dukungan sosial, Remaja, Sekolah.

\section{OVERVIEW OF PERCEIVED SOCIAL SUPPORT FROM TEACHER BY HIGHSCHOOL " $X$ ” STUDENTS}

\begin{abstract}
Teachers have an important role in educating students well. One way that teachers can do to be able to increase motivation and school engagement is by providing social support to students. This study aims to find out the overview of perceived social support from teachers by high school " $X$ " students in South Tangerang. The research method is descriptive qualitative research with data collection techniques through focus group discussions and structured interviews. The results of data retrieval show that the perceived social support from some teachers by high school " $X$ " students is quite satisfying for students but not from every teachers. This means it can still be improved again. This is because not all teachers are considered good enough at providing social support to students. The total number of teachers are 17 people and for students are 67. It should be able to be improved in communication skills so that they can provide better social support to students.
\end{abstract}

Keywords : Adolescent, School, Social support.

\section{PENDAHULUAN}

Peringkat Kualitas pendidikan Indonesia tergolong rendah, Berdasarkan data dari data Programme for International Students Assessment atau PISA tahun 2015, Indonesia berada pada 
peringkat 62 dari 70 negara. Rendahnya kualitas pendidikan di Indonesia ini cukup meresahkan. Untuk dapat meningkatkan kualitas pendidikan, guru memiliki peran yang penting. Menurut Menteri Pendidikan dan Kebudayaan (Mendikbud), Muhadjir Effendy, dikatakan bahwa ketika guru mampu membantu siswa dalam mencapai keberhasilan dan berperan dalam membangun dan membentuk karakter siswa, hal ini dapat mendorong siswa untuk berperan lebih aktif di sekolah (Debora, 2016).

Fenomena di atas menunjukkan bahwa dukungan sosial merupakan salah satu hal yang dapat meningkatkan keaktivan siswa di sekolah yang kemudian dapat berdampak pada motivasi belajar siswa. Hal ini didukung dengan penelitian Wang dan Eccles (2012) yang menunjukkan korelasi positif antara dukungan sosial yang diterima siswa dengan keterlibatan siswa di sekolah. Hasil penelitian Kozan, Fabio, Blustein, dan Kenny (2013) juga menunjukkan hasil yang sejalan. Dalam penelitian, dukungan sosial dari guru muncul sebagai penentu penting terhadap keterlibatan siswa di sekolah, sedangkan dukungan sosial dari keluarga dan teman sebaya bukan penentu yang signifikan. Pada penelitian Cheon dan Reeve (2015) juga mengatakan bahwa ketika guru lebih mendukung siswa secara otonomi dan tidak terlalu mengontrol atau mengekang siswa, maka siswa dapat merasa lebih puas secara kebutuhan psikologis karena ketiga faktor dari kebutuhan tersebut terpenuhi. Guru juga menjadi lebih mendengarkan kebutuhan dan kritik dari siswa untuk dapat segera dibantu atau ditangani.

Penelitian Gutiérrez, Tomás, Romero, dan Barrica (2017) juga memiliki hasil yang sejalan. Hasil menunjukkan bahwa dukungan sosial dari guru memprediksi serangkaian indikator dari keterlibatan di sekolah, diwakili dengan partisipasi siswa di sekolah, identifikasi siswa terhadap sekolah, dan penggunaan strategi regulasi diri. Siswa yang merasa didukung oleh guru cenderung memenuhi ekspektasi yang dimiliki guru dan mengurangi perilaku mengganggu atau menyimpang. Hasil penelitian ini juga menunjukkan bahwa dengan adanya dukungan sosial yang tinggi, siswa akan merasa puas dengan sekolah. Hal ini dapat mengurangi perilaku negatif seperti apatisme.

Berdasarkan pemahaman di atas, penelitian yang akan penulis lakukan bertujuan untuk mencari tahu gambaran dukungan sosial guru yang dirasakan oleh siswa di salah satu Sekolah Menengah Atas (SMA) swasta di Tangerang selatan. Berdasarkan hasil wawancara pre-eliminari yang telah penulis lakukan, ditemukan pernyataan bahwa keterlibatan siswa di sekolah cukup rendah. Hal ini terlihat dari banyaknya siswa yang sering terlambat datang, tidak hadir, serta motivasi belajar dan fokus belajar siswa di kelas yang rendah. Hasil yang ingin dicapai dari penelitian ini adalah mengetahui gambaran dukungan sosial dari guru yang dirasakan oleh siswa sekolah tersebut. Penelitian akan dilakukan pada SMA swasta " $X$ ", dengan jumlah guru yang mengajar di SMA " $X$ " berjumlah 17 orang dengan siswa berjumlah 67 orang.

\section{METODOLOGI PENELITIAN}

Pada penelitian ini metode penelitian yang digunakan adalah metode penelitian kualitatif deskriptif. Teknik pengumpulan data yang dipakai adalah dengan melakukan focus group discussion atau FGD dan wawancara. FGD dilakukan pada sejumlah siswa dari setiap angkatan dengan topik yang membahas mengenai dukungan sosial yang dirasakan oleh siswa dan mencari tahu mengenai perasaan mereka mengenai dukungan sosial tersebut. FGD juga dilakukan untuk melihat seperti apa hubungan dengan guru dari sudut pandang siswa. Hal ini dilakukan untuk mencari tahu apakah siswa merasakan dukungan sosial yang didapatkan dari pihak guru dan sekolah.

Dalam melakukan FGD penulis membagi FGD ke dalam dua pertemuan. Pertemuan pertama adalah FGD dengan kelas 10 dan pertemuan kedua adalah FGD dengan kelas 11. Setiap FGD terdiri dari enam orang peserta, tiga orang merupakan siswa kelas 10 IPA dan tiga orang dari kelas 10 IPS. Begitu juga dengan FGD pada kelas 11 yang juga terdiri dari enam orang peserta. Tiga orang merupakan siswa kelas 11 IPA dan tiga orang lainnya merupakan siswa kelas 11 IPS.

Saat FGD dimulai, penulis memperkenalkan diri dan menjelaskan bahwa FGD bertujuan untuk kepentingan penelitian. Kemudian partisipan diberikan lembar informed consent dan diminta 
izin untuk direkam secara audio sepanjang FGD dilakukan. Pada saat FGD berlangsung, penulis akan membacakan satu persatu materi diskusi kemudian meminta partisipan untuk berdiskusi. Beberapa jawaban partisipan akan dicatat oleh penulis sebagai data tambahan selain hasil rekaman. Setelah semua materi selesai didiskusikan, penulis menutup FGD dan melakukan debriefing mengenai FGD yang dilakukan untuk penelitian mengenai dukungan sosial. Durasi FGD berlangsung selama $30-45$ menit.

Tabel 1. Materi Bahan Diskusi Focus Group Discussion

\begin{tabular}{|c|c|}
\hline Indikator & Materi \\
\hline \multirow[t]{2}{*}{ Dukungan Sosial } & $\begin{array}{l}\text { Seberapa besar peran guru dalam membantu menyelesaikan } \\
\text { masalah siswa }\end{array}$ \\
\hline & $\begin{array}{l}\text { Seberapa besar peran bimbingan konseling dalam membantu } \\
\text { menyelesaikan masalah siswa }\end{array}$ \\
\hline \multirow{5}{*}{$\begin{array}{l}\text { Keterlibatan siswa di } \\
\text { Sekolah }\end{array}$} & Pengalaman menyenangkan siswa selama di sekolah \\
\hline & Pengalaman menyebalkan siswa selama di sekolah \\
\hline & Pendapat siswa mengenai peraturan di sekolah \\
\hline & Masalah yang dihadapi siswa di sekolah \\
\hline & $\begin{array}{l}\text { Harapan yang diinginkan siswa selama bersekolah di SMA " } X \text { ". } \\
\text { Bagaimana mencapainya? }\end{array}$ \\
\hline
\end{tabular}

Wawancara terstruktur dilakukan untuk mendapatkan informasi secara langsung mengenai perilaku yang ingin diubah. Dalam konteks ini, wawancara terstruktur akan dilakukan terhadap sejumlah guru dan siswa. Wawancara pada guru dilakukan untuk mengetahui seperti apa saja dukungan sosial yang ada atau diberikan kepada siswa, serta apa saja dampak dan efek yang didapat dari dukungan sosial tersebut. Selain kepada guru, wawancara juga dilakukan kepada sejumlah siswa untuk mengetahui apa saja jenis dukungan sosial yang dirasakan oleh mereka. Wawancara juga bertujuan untuk mengetahui sumber mana saja yang dirasakan oleh siswa memberikan dukungan sosial kepada mereka.

\section{HASIL DAN PEMBAHASAN}

\section{Hasil Focus Group Discussion}

Penulis melakukan FGD sebanyak dua kali pada tanggal 4 Maret 2019, dengan partisipan siswa kelas 10 dan 11. Hasil yang didapatkan dari dua kelompok FGD tidak jauh beda dengan data wawancara. Data yang didapatkan dari hasil wawancara cenderung mengkonfirmasi mengenai hasil FGD. Sehingga data yang didapatkan saling menguatkan satu sama lainnya. Data yang muncul selama FGD adalah, jumlah siswa yang sedikit, guru yang tidak menyenangkan dan kurang dalam memahami siswa atau mendengarkan apresiasi mereka, kepala sekolah yang galak, pergantian guru BK yang terlalu sering sehingga siswa merasa sulit untuk beradaptasi dengan guru BK yang baru dan menyebabkan mereka jarang bercerita kepada guru BK. Padahal siswa berpendapat bahwa guru BK memiliki peran penting terutama dalam membantu menghadapi masalah yang siswa hadapi.

Kegiatan FGD kelas 11 dilakukan pada hari Senin tanggal 4 Maret 2019 dengan durasi selama 51 menit. Siswa kelas 11 tampak menjawab pertanyaan dan berdiskusi dengan antusias dan banyak mengeluarkan keluh kesah. Kegiatan FGD kelas 10 dilakukan pada hari yang sama dengan durasi selama 32 Menit. Siswa kelas 10 menjawab pertanyaan dan berdiskusi dengan lancar tetapi tampak banyak keraguan dalam menjawab dengan terbuka. 
Dari kedua FGD yang telah dilakukan, ditemukan terdapat beberapa masalah yang dihadapi siswa di sekolah. Masalah yang muncul adalah permasalahan siswa dengan guru BK di sekolah. Siswa menganggap bahwa guru BK seharusnya menjadi temp at curhat yang nyaman. Sering bergantinya guru BK membuat siswa merasa tidak nyaman. Pada Saat FGD, beberapa siswa mengeluhkan kalau mereka tidak pernah bercerita kepada guru BK karena wajah guru tersebut garang dan membuat mereka takut. Salah seorang siswa juga mengeluhkan bahwa ketika mereka bercerita, guru BK tersebut beralih bercerita mengenai pengalaman pribadinya. Hal ini membuat siswa malas untuk bercerita kembali. Seorang siswa lain juga mengeluhkan bahwa tidak adanya guru BK menyebabkan pihak sekolah sempat menetapkan guru bagian kesiswaan untuk membantu masalah siswa. Akan tetapi hal itu tidak membuat siswa senang. Siswa beranggapan bahwa guru kesiswaan menambahkan beban bagi mereka dan tidak dapat memberikan solusi. Siswa juga mengatakan bahwa guru tersebut malah menyalahkan mereka atas curhatan masalah yang mereka ceritakan.

Masalah lain yang muncul adalah guru tidak mempercayai siswa terutama ketika siswa memberi alasan keterlambatan mereka. Seorang siswa kelas 11 mengeluhkan bahwa ketika seorang siswa memberikan alasan mengapa mereka terlambat, apapun alasannya, baik apakah disebabkan oleh cuaca, atau kecelakaan, guru tidak akan mau percaya selama alasan tersebut tidak berasal atau dikatakan oleh orangtua siswa.

Selain itu, banyaknya freeclass menyebabkan siswa merasa datang ke sekolah adalah hal yang sia-sia. Siswa beranggapan bahwa banyaknya freeclass atau kelas kosong membuat mereka merasakan bahwa sekolah tidak produktif. Mereka juga berharap setidaknya ketika memberikan tugas untuk freeclass, guru mempertimbangkan beban tugas tersebut. Seringkali guru meninggalkan siswa dengan tugas yang belum pernah diajarkan dan terlalu banyak bagi rentang waktu freeclass yang hanya berkisar 2 jam.

Dari FGD yang telah dilakukan juga ditemukan hasil bahwa peran guru dan guru BK dalam membantu menyelesaikan masalah siswa cukup baik tetapi kurang dalam segi penyelesaian masalah. Siswa mengeluhkan bahwa ketika guru diceritakan mengenai masalah yang mereka hadapi, guru tidak terlalu memberi saran atau solusi yang efektif. Siswa juga mengeluhkan bahwa mereka tidak dapat sepenuhnya mempercayai guru maupun guru BK untuk menceritakan masalah mereka. Beberapa siswa mengeluhkan ketika mereka bercerita atau konsultasi kepada guru BK yang ada, masalah yang mereka ceritakan berakhir diketahui oleh kepala sekolah meskipun mereka tidak menginginkan hal tersebut terjadi. Secara kolektif siswa kelas 11 yang mengikuti FGD sepakat bahwa kebanyakan guru tidak dapat dipercaya. Meskipun guru-guru tersebut menyenangkan untuk diajak berbicara atau mengobrol, hal-hal yang mereka ceritakan berakhir diketahui oleh guru lain atau pihak sekolah.

Dari FGD yang telah dilakukan juga ditemukan mengenai pengalaman yang tidak menyenangkan bagi siswa di sekolah. Pengalaman tersebut berupa guru yang tidak mendengarkan pendapat siswa dan kurang tegas dalam mengajar. Salah satu siswa bercerita bahwa seorang guru terlalu baik dan pasif dalam mengajar. Ketika siswa bermain telepon genggam di kelas ketika pelajaran berlangsung, guru tidak melakukan apa-apa. Siswa juga mengeluhkan bahwa pihak sekolah kurang mendukung acara siswa, terutama dalam bentuk dana untuk acara siswa. Salah satu hal yang dikeluhkan siswa adalah ketika ada acara sekolah, mereka hanya diberikan dana sedikit yang menyebabkan acara yang diadakan hanyalah pas-pasan atau seadanya saja.

Berdasarkan hasil FGD yang telah dilakukan dapat disimpulkan bahwa siswa menginginkan agar aspirasi mereka didengarkan, baik dari para guru, guru BK, dan dari pihak sekolah. Peran guru dan guru BK dalam membantu menyelesaikan masalah siswa cukup baik tetapi kurang dalam segi penyelesaian masalah. Siswa juga mengeluhkan bahwa mereka tidak dapat sepenuhnya mempercayai guru maupun guru BK untuk menceritakan masalah mereka. Selain itu juga ditemukan mengenai pengalaman yang tidak menyenangkan bagi siswa di sekolah. Pengalaman tersebut berupa guru yang tidak mendengarkan pendapat siswa, kurang tegas dalam mengajar, dan pihak 
sekolah tidak mendukung acara siswa. Siswa mengatakan bahwa banyaknya waktu belajar yang kosong atau freeclass membuat mereka merasa datang ke sekolah merupakan hal yang sia-sia. Pihak sekolah juga kurang mendukung dalam segi pemberian dana untuk kegiatan dana cara siswa di sekolah.

\section{Hasil Wawancara Guru}

Dalam penelitian ini dilakukan wawancara terhadap sejumlah guru, yakni sebanyak empat orang, dua guru laki-laki dan dua guru perempuan. Proses wawancara berlangsung selama 30 - 60 menit. Wawancara dilakukan selama dua hari pada tanggal 6 Maret dan 8 Maret. Penulis merekrut partisipan dengan cara meminta izin kepada kepala sekolah dan mencari guru mana saja yang sedang tidak sibuk. Penulis kemudian menyerahkan informed consent serta menanyakan kesediaan partisipan untuk diwawancarai. Beberapa aspek yang ditanyakan selama wawancara adalah dukungan sosial yang diberikan guru terhadap siswa dan keterlibatan siswa di sekolah. Berdasarkan aspek-aspek tersebut, penulis mendapatkan data yang menggambarkan keadaan sekolah X.

Berdasarkan jawaban di atas, dapat disimpulkan bahwa hal yang menjadi pertimbangan guru mengenai siswa di sekolah adalah pergaulan siswa dengan lingkungan luar. Seorang guru berinisial Pak $\mathrm{R}$ mengatakan bahwa pergaulan siswa adalah hal yang perlu diperhatikan. Hal ini dikarenakan perbedaan kondisi karakter siswa dari SMP ke SMA, dimana beberapa karakter siswa pada saat SMP masih melekat, terutama ketika siswa masih berada pada kelas 10 . Pak $\mathrm{R}$ juga beranggapan bahwa masih terjadi proses pencarian jati diri, dimana hal ini seharusnya menjadi perhatian seorang guru untuk dapat menjaga siswa agar sesuai dengan apa yang diinginkan orangtua dan sekolah. Sejalan dengan pendapat Pak $\mathrm{R}$, guru dengan inisial Pak $\mathrm{H}$ juga beranggapan serupa. Beliau beranggapan bahwa pergaulan siswa di luar sekolah, dengan kategori teman yang tidak berasal dari sekolah yang sama merupakan hal yang berbahaya dan perlu diwaspadai. Hal ini dikarenakan guru tidak tahu mengenai latar belakang teman-teman siswa tersebut.

Motivasi dan daya juang belajar siswa yang rendah juga menjadi pertimbangan guru di sekolah. Berdasarkan dari hasil wawancara dengan Pak $\mathrm{R}$ juga ditemukan bahwa menurut beliau, motivasi belajar yang ada pada siswa SMA "X" dianggap kurang. Beliau menceritakan mengenai pengalaman ketika mengajar. Siswa sudah diajarkan dan dijelaskan secara lengkap dan mendetail tetapi ketika ulangan selalu mendapatkan nilai rendah. Ketika guru bertanya apakah siswa belajar sebelum ujian, siswa menjawab bahwa mereka hanya belajar sekadarnya atau tidak belajar sama sekali. Pak R juga mengatakan bahwa ketika siswa menemukan soal dimana mereka merasa tidak bisa atau tidak benar-benar sama dengan contoh yang pernah dijelaskan, siswa tidak paham dan tidak mencoba mencari tahu. Siswa tampak kebingungan dan tidak tahu cara mengerjakan sebuah soal ketika soal tersebut berbeda sedikit dengan apa yang pernah diajarkan oleh guru.

Hal ini didukung oleh jawaba dari hasil wawancara dengan ibu D. Beliau mengeluhkan bahwa siswa sudah ditawarkan sesi belajar tambahan di sore hari setelah sekolah selesai. Akan tetapi tidak semua siswa datang, beberapa siswa meskipun telah membuat janji seringkali tidak datang. Ketika lbu $\mathrm{D}$ menanyakan kenapa tidak datang, siswa hanya menjawab bahwa mereka lupa ada sesi belajar tambahan di sore hari.

Selain itu, sinkronisasi atau kerja sama dengan sekolah atau yayasan juga dianggap kurang oleh guru. Pak $\mathrm{R}$ menceritakan bahwa siswa sebenarnya memiliki potensi besar dalam beragam bidang ilmu. Salah seorang siswa berhasil mendapatkan juara dua nasional di UGM meneliti tentang rayap. Hal ini dapat dicapai dengan melakukan penelitian di IPB. Akan tetapi untuk dapat melakukan hal ini diperlukan dukungan dana dari sekolah. Hal ini terbatasi oleh sekolah yang membatasi pengeluaran dana dikarenakan siswa yang sedikit. Pihak yayasan juga menganggap bahwa SMA " $X$ " masih belum dapat memberikan sesuatu kepada Yayasan, yang menyebabkan dukungan dana tidak begitu banyak. Padahal guru beranggapan bahwa hal itu diperlukan untuk dapat mendukung siswa untuk meraih prestasi di luar mata pelajaran. 
Tidak hanya itu, perhatian guru juga berfokus mengenai orang tua yang memanjakan dan tidak melakukan follow-up dengan apa yang sudah diberikan di sekolah. Guru mengeluhkan bahwa terkadang pengawasan dari pihak orang tua juga diperlukan. Kendala terjadi ketika sebuah kebiasaan baik sudah dibentuk di sekolah tetapi hal tersebut akan menjadi sia-sia ketika di rumah tidak dilakukan follow-up oleh orang tua siswa. Pak $\mathrm{R}$ berpendapat bahwa kegiatan siswa di sekolah kurang lebih sekitar 8 jam, dan setelah itu dibutuhkan pengawasan orang tua terutama di luar sekolah.

Guru juga merasa bahwa siswa tidak punya target pribadi dan cepat puas disertai manajemen waktu siswa yang rendah. Berdasarkan wawancara dengan lbu $A$, beliau berpendapat bahwa pola asuh siswa yang berangkat dari keluarga yang berbeda menyebabkan hal tersebut terjadi. Ketika pola asuh keluarga memudahkan siswa untuk mendapatkan segala sesuatu, maka akan timbul masalah yaitu rendahnya daya juang siswa dan motivasi untuk berprestasi. Hal ini menghambat siswa dalam berupaya lebih keras atau untuk belajar lebih terutama untuk akademik. Ibu A juga berpendapat bahwa mudahnya siswa mendapatkan segala sesuatu dari orangtua menyebabkan mereka menjadi tidak tertantang. Ibu A mengeluhkan beberapa orang tua terkadang menghambat proses siswa dalam belajar karena ketika siswa tidak bisa, orang tua seringkali berkata pada guru untuk tidak memaksakan siswa sampai bisa. Padahal hal tersebut sebenarnya bermanfaat bagi siswa untuk merasa lebih tertantang dan mengatasi masalah yang dihadapi.

Berdasarkan jawaban di atas, dapat disimpulkan bahwa hal yang menjadi pertimbangan guru mengenai siswa di sekolah adalah pergaulan siswa dengan lingkungan luar, motivasi dan daya juang belajar siswa yang rendah, sinkronisasi atau kerja sama dengan sekolah atau yayasan, orang tua yang memanjakan dan tidak melakukan follow-up dengan apa yang sudah diberikan di sekolah, siswa tidak punya target pribadi dan cepat puas, serta manajemen waktu siswa yang kurang.

Guru juga menyampaikan cara mengatasi masalah dengan menggali potensial siswa, memberi kesempatan bagi siswa untuk berprestasi, mendorong dan memotivasi siswa untuk terus berprestasi, melibatkan siswa dalam melakukan tanggung jawab di sekolah seperti memberi siswa peran di kelas. Guru menceritakan bahwa biasanya mereka melakukan penggalian potensi pada setiap siswa secara spesifik. Setelah didapatkan apakah potensi siswa, guru kemudian akan memberikan challenge atau tantangan untuk mengasah potensi siswa. Tantangan juga diberikan dalam bentuk pemberian peluang bagi siswa untuk dapat berprestasi. Hal ini dapat berupa lombalomba yang bisa diikuti, atau mendorong siswa untuk berpartisipasi dalam kepanitiaan ketika terdapat kegiatan atau event.

Ibu A menceritakan bahwa ketika siswa didorong untuk terus berprestasi dan terus diberikan motivasi, siswa SMA "X" terbukti mampu untuk meraih hal tersebut. Hal ini terlihat dari salah satu siswa yang menjadi juara satu KIR di Thailand dan mendapatkan medali emas. Tidak hanya itu, terdapat siswa yang menggemari robotik yang kemudian dikirimkan ke ITS untuk belajar lebih lanjut. Siswa tersebut kemudian meraih juara satu internasional dalam robotik dan kemudian berkuliah ke ITS sesuai dengan minatnya. Hal ini dapat dicapai dengan adanya dukungan dan motivasi dari pihak sekolah serta orangtua. Selain itu, guru juga melibatkan siswa untuk saling memiliki tanggung jawab di kelas. Siswa akan digilir dalam melakukan tanggung jawab tersebut sehingga mereka semua saling merasakan dan mengetahui manakah bidang yang paling diminati atau dikuasai.

Tidak hanya itu, guru juga memberikan gagasan untuk mengatasi masalah seperti dengan memberi fasilitas dalam mengasah bakat siswa. Guru akan menyiapkan fasilitas bagi siswa untuk mengasah bakat dan minat siswa. Fasilitas tidak harus berupa fasilitas fisik, tetapi juga dapat berupa dukungan dari guru serta dorongan berupa motivasi dan pemberian kesempatan bagi siswa. Salah satu guru mengeluhkan bahwa seharusnya kegiatan ekstrakurikuler bisa menjadi salah satu sarana dalam memberikan fasilitas pada siswa untuk berkarya. Akan tetapi karena sekolah masihlah baru dan memiliki siswa yang hanya sedikit, dana tidaklah mencukupi dan pihak Yayasan pun membatasi kegiatan. Hal ini menyebabkan siswa hanya berfokus pada akademik yang hanya akan bagus di rapot. Pak $\mathrm{R}$ berpendapat bahwa sebenarnya siswa tidak apa-apa memiliki akademik yang tidak terlalu bagus tetapi perlu memiliki bakat tertentu yang sebaiknya dikembangkan di sekolah. 
Guru juga perlu mampu memberi evaluasi terhadap siswa melalui diskusi dua arah. Ibu A mengatakan bahwa siswa akan patuh ketika guru mampu menyampaikan pesan dan berkomunikasi dengan baik. Pak $\mathrm{H}$ berpendapat bahwa dengan memberikan pemahaman yang positif dan menyentuh pemahaman siswa dengan hal yang masuk akal dan personal akan membuat siswa merasa dihargai dan mau mempertimbangkan masukan dari guru.

Selain itu, guru juga menyarankan untuk mengenal keluarga siswa dengan dekat seperti melakukan kunjungan ke rumah, koordinasi dengan orang tua di rumah, melakukan komunikasi dengan tepat dan dapat memberi sentuhan personal. Berdasarkan hasil wawancara dengan ibu A, beliau berpendapat bahwa guru sebaiknya dapat hadir dalamkeluarga siswa. Beliau memutuskan untuk dapat melakukan visitation atau kunjungan ke rumah siswa tidak hanya sebagai guru tetapi sebagai saudara. Hal ini diharapkan dapat membuat pihak sekolah dan pihak keluarga siswa dapat lebih saling mengenal dan dapat membicarakan perkembangan siswa dengan lebih baik dan mendalam.

Hasil wawancara dengan Ibu $D$ juga menunjukkan pemahaman yang sejalan dengan ibu $A$. Beliau mengatakan bahwa ia sering melakukan diskusi terbuka di dalam kelas. Ibu $D$ akan bertanya kepada siswa mengenai masalah yang dihadapi saat proses belajar mengajar berlangsung. Ibu $D$ melakukan pertanyaan terbuka untuk melihat masukan dari siswa dan akan mempertimbangkan masukan-masukan tersebut. Hal ini membuat siswa merasa dihargai dan guru juga mampu mencari solusi yang lebih tepat dalam mengatasi masalah di dalam kelas.

Guru berpendapat bahwa dengan membuat kelompok kecil atau tutor sebaya dapat meningkatkan motivasi siswa. Berdasarkan hasil wawancara dengan lbu $D$, beliau melakukan pembentukan kelompok kecil atau tutor sebaya. Di kelas beliau memasangkan setiap anak dengan temannya untuk mempermudah proses belajar. Diharapkan dengan adanya bantuan teman belajar, siswa dapat saling berdiskusi mengenai pelajaran atau materi yang membingungkan. Ibu $D$ juga memberikan soal dimana siswa dapat melakukan diskusi secara berpasangan untuk mempermudah pemahaman mata pelajaran yang dianggap sulit. Ibu $\mathrm{D}$ juga memberikan tawaran belajar tambahan setelah pulang sekolah, serta memahami siswa secara mendalam untuk mengetahui minat serta potensi mereka. Beliau juga berharap dapat mengajarkan siswa bagaimana cara berkomunikasi dengan lingkungan dan menghadapi masyarakat.

Berdasarkan hasil wawancara dengan guru di atas dapat disimpulkan bahwa guru SMA " $X$ " memiliki pendapat yang beragam mengenai apa yang perlu ditingkatkan dan menjadi pertimbangan bagi siswa SMA "X". Meskipun begitu setiap guru yang diwawancara sepakat bahwa siswa memiliki motivasi dan daya juang belajar yang rendah. Selain itu guru juga sepakat bahwa sinkronisasi dan kerja sama dengan sekolah dan orang tua siswa perlu ditingkatkan. Untuk dapat mengatasi hal tersebut, guru-guru juga memberikan gagasan bagaimana cara mengatasi permasalahan yaitu dengan menggali potensi siswa dan terus memberikan motivasi kepada siswa. Guru juga sependapat untuk memberikan evaluasi kepada siswa dengan melakukan diskusi dua arah dan membuat kelompok kecil atau tutor sebaya.

\section{Hasil Wawancara Siswa}

Dalam penelitian ini melakukan wawancara terhadap sejumlah siswa kelas 10 dan 11. Siswa kelas 10 yang diwawancara berjumlah 4 orang yaitu 2 laki-laki dan 2 perempuan, begitu juga dengan siswa kelas 11 yang diwawancara berjumlah 4 orang yaitu 2 laki-laki dan 2 perempuan. Proses wawancara berlangsung selama 30 - 60 menit, dilakukan pada tanggal 12 Maret 2019. Beberapa aspek yang ditanyakan selama wawancara adalah dukungan sosial yang dirasakan siswa dan keterlibatan siswa di sekolah. Berdasarkan aspek-aspek tersebut, penulis mendapatkan data yang menggambarkan keadaan sekolah " $X$ ".

Dari delapan wawancara yang telah dilakukan ditemukan hasil bahwa terdapat beberapa hal positif dan negatif mengenai guru berdasarkan pendapat siswa. Hal positif dan disukai siswa dari guru SMA "X" adalah kemampuan guru dalam memberi motivasi, dukungan, serta memberi 
kesempatan kepada semua siswa secara adil dan merata. Guru juga seringkali mendorong siswa untuk terus mengasah kemampuan yang mereka miliki.

Seorang siswa kelas 11 IPA berinisial Y mengatakan bahwa hal yang disukai oleh siswa dari guru favoritnya di SMA "X" adalah karena beliau memiliki kepribadian yang fleksibel dan dapat diajak berargumen maupun mengobrol biasa. Guru tersebut juga bisa menjadi teman diskusi yang menyenangkan. $Y$ berpendapat bahwa komunikasi dengan siswa yang lancar merupakan salah satu hal penting yang perlu dimiliki oleh semua guru, sehingga siswa dapat dengan nyaman mengungkapkan perasaan dan pendapat mereka. $Y$ juga beranggapan bahwa dalam teknik belajar mengajar, komunikasi yang bersih dan lancar merupakan salah satu faktor yang penting. Apabila terdapat hal yang menghambat komunikasi antara guru dan siswa, hal itu dapat mempersulit berlangsungnya pembelajaran.

Siswa kelas 11 IPA dengan inisial $\mathrm{N}$ berpendapat bahwa hal yang disukai dari guru favoritnya adalah karena beliau menyenangkan untuk diajak berbicara dan suka bercanda. $\mathrm{N}$ juga mengatakan bahwa guru tersebut mampu memberikan nasihat yang bagus dan bermanfaat. Guru yang dapat memahami siswa dengan baik juga disukai oleh siswa, dimana hal ini mempermudah mereka untuk lebih terbuka dan bercerita mengenai masalah yang dihadapi.

Di sisi lain, hal negatif yang tidak disukai siswa dari guru SMA " $X$ " adalah beberapa guru tidak mau mendengarkan siswa di mana mereka seringkali memberikan kritik kepada siswa tanpa mendengarkan mereka terlebih dahulu, kemampuan komunikasi yang kurang tepat, serta tidak mampu memberikan solusi terhadap masalah yang dihadapi oleh siswa. Seorang siswa kelas 11 IPA dengan inisial $\mathrm{N}$ mengeluhkan bahwa tergantung kondisi dan situasi, guru bisa menjadi sangat menyenangkan, tetapi juga bisa menjadi menyebalkan. Persentase guru yang sudah mampu berkomunikasi dengan baik kepada siswa dari total seluruh guru di SMA "X" menurut N sekitar 40\% guru. Tidak semua guru dapat memberikan motivasi dengan baik kepada siswa. Seringkali guru hanya dapat memberikan solusi yang kurang memuaskan, atau hanya memberikan solusi tanpa mampu mendampingi siswa menghadapi masalah. Siswa $\mathrm{N}$ berpendapat bahwa kekurangan guru di SMA "X" adalah kemampuan berkomunikasi mereka dengan siswa.

Beberapa siswa juga mengeluhkan bahwa terdapat beberapa guru yang bermuka dua. Siswa berinisial A mengatakan bahwa guru-guru jenis ini mengatakan hal yang berbeda di hadapan pihak siswa dan dihadapan pihak Yayasan. Hal ini menyebabkan A kurang dapat mempercayai sebagian besar guru di sekolah. Tidak hanya itu, seorang siswa lain mengatakan bahwa beberapa guru masih memaksakan kehendaknya terhadap siswa untuk menaati peraturan. Seorang guru bahkan tidak mau mendengarkan masukan atau pendapat dari siswa.

Bagi siswa sendiri, ditemukan bahwa guru yang ideal adalah guru yang fleksibel dan mau diajak berdiskusi. Guru yang ideal juga merupakan guru yang mampu berkomunikasi dengan baik, dan mendengarkan pendapat siswa. Berdasarkan hasil wawancara dengan siswa kelas 11 IPS dengan inisial $\mathrm{A}$, ia mengatakan bahwa guru yang ideal baginya adalah guru yang dapat dipercaya omongannya, konsisten, dan jujur.

A juga berpendapat bahwa tugas utama seorang guru adalah mengaja, dimana hal tersebut berarti bahwa seorang guru yang ideal baginya adalah memiliki cara mengajar yang tidak membosankan. Guru juga harus paham situasi dan kondisi serta batasan kapan guru harus mengajar dengan seirus, atau kapan guru dapat bercanda dengan siswa. A berpendapat bahwa terlalu banyak bercanda ketika pembelajaran berlangsung membuatnya merasa bahwa masuk sekolah adalah hal yang sia-sia. Tidak hanya itu, A juga berpendapat bahwa guru yang ideal adalah guru yang mau dan bisa mendengarkan pendapat dari siswa.

Berdasarkan hasil wawancara dengan siswa juga didapatkan juga apa yang merupakan masalah di sekolah yaitu, tidak adanya guru BK, kesulitan beradaptasi dengan guru BK yang terus berganti, sulit mempercayai guru untuk bercerita. Siswa berinisial N dari kelas 11 IPA mengatakan bahwa kendala yang ia rasakan adalah terkadang guru terlihat menahan diri untuk memberi izin kepada siswa dalam melakukan kegiatan karena dorongan dari sekolah. Terkadang $\mathrm{N}$ juga 
merasakan bahwa beberapa guru berusaha memotivasi siswa tetapi memiliki cara berkomunikasi yang kurang tepat. Beberapa guru melakukan motivasi di tengah-tengah pelajaran yang berakhir menjadi ceramah panjang, dimana hal ini mengakibatkan pelajaran terpotong dan siswa merasa waktu mereka terbuang secara sia-sia.

Padahal bagi siswa, tugas guru adalah membantu ketika ada masalah, memberikan arahan dan membimbing siswa serta berperan sebagai teman. Seorang siswa kelas 11 IPA berinisial $Y$ mengeluhkan bahwa seorang guru seharusnya mampu mengarahkan siswa diluar pendidikan formal atau akademis. Guru diharapkan mampu mendidik dan memberikan pelajaran bagi siswa mengenai hal-hal yang lebih teknis. $Y$ beranggapan bahwa program mentorship yang ada di SMA " $X$ " sudah bagus, dimana siswa mendapatkan waktu untuk berdiskusi dengan guru mengenai tujuan hidup, bakat masing-masing siswa, serta minat penjurusan kuliah. Akan tetapi frekuensi adanya mentorship sekarang menurun, padahal $Y$ beranggapan bahwa mentorship merupakan hal yang penting dan dapat membantu hubungan antara siswa dan guru di sekolah.

Hasil wawancara juga menunjukkan bahwa siswa senang bersekolah di SMA "X" tetapi tidak bangga. Hal ini terlihat dari wawancara beberapa siswa. $Y$ mengatakan bahwa dulu ia bangga bersekolah di SMA "X". Y membanggakan bahwa di sekolahnya ia boleh berambut panjang dan tidak terlalu memiliki peraturan yang ketat mengenai seragam sekolah. Setelah peraturan sekolah diperketat, $Y$ merasa tidak bangga lagi bersekolah di SMA " $X$ ".

Begitu juga dengan A dari kelas 11 IPS. A mengatakan bahwa alasan utama ia memilih SMA " $X$ " adalah karena gurunya. la mendapatkan info dari kakaknya yang merupakan alumni dari SMA " $X$ " yang mengatakan bahwa guru-guru di SMA "X" berbeda dari guru SMA lain. A mendapatkan informasi bahwa guru-guru tersebut ramah dan bersahabat serta mampu berteman akrab dengan siswanya. Namun A merasa kecewa ketika masuk SMA "X" karena terdapat perubahan peraturan dimana hal ini berimbas dengan perubahan guru-guru yang sekarang kurang dekat dengan siswa. Hal lain yang disayangkan oleh $\mathrm{A}$ adalah banyaknya guru lama yang sudah akrab dan dekat dengan siswa berakhir pindah sekolah atau keluar dari SMA "X". A mengeluhkan bahwa tahun 2019 ini adalah tahun dimana paling banyak terjadi keluarnya guru dari SMA " $X$ ".

Berdasarkan hasil wawancara dengan siswa SMA " $X$ " dapat disimpulkan bahwa siswa merasa guru SMA " $X$ " sebagian besar sudah menyerupai guru ideal bagi mereka. Guru ideal yang dimaksud oleh siswa adalah guru yang fleksibel, bisa diajak berdiskusi, mampu berkomunikasi dengan baik, dan mendengarkan pendapat siswa. Meskipun begitu siswa masih merasa sulit untuk mempercayai guru dalam menceritakan permasalahan mereka yang dikarenakan guru BK yang terus berganti. Siswa juga merasa bahwa berskolah di SMA " $X$ " itu menyenangkan tetapi tidak membanggakan karena adanya image sekolah yang tidak baik di masyarakat.

\section{KESIMPULAN}

Dari data hasil baseline yang sudah dijelaskan sebelumnya dapat disimpulkan bahwa secara keseluruhan siswa merasa bahwa siswa merasakan dukungan sosial yang didapat dari pihak guru cukup baik. Akan tetapi mereka masih merasa kurang mendapatkan dukungan dari pihak sekolah maupun beberapa guru dan guru BK. Hal ini terlihat dari hasil FGD dimana siswa mengatakan bahwa mereka merasa kurang didengarkan aspirasinya dan bahkan tidak begitu dipercaya ketika memberikan alasan keterlambatan. Siswa juga menyatakan kurang percayanya mereka untuk dapat menyampaikan masalah yang dihadapi kepada guru BK karena takut masalahnya tersebar atau diberitahukan kepada kepala sekolah. Penemuan hasil ini didukung dengan hasil wawancara terstruktur dengan beberapa siswa yang menunjukkan bahwa masih banyak guru yang sering memberikan kritik tanpa mendengarkan sudut pandang siswa terlebih dahulu dan kurangnya kemampuan komunikasi beberapa guru terhadap siswa.

Meskipun demikian, hasil wawancara dengan siswa juga menunjukkan bahwa siswa beberapa guru sudah baik dalam memberikan dukungan dan dalam berkomunikasi dengan siswa. 
Hal ini dapat dilihat dari pernyataan siswa yang menyatakan bahwa beberapa guru sering memotivasi mereka untuk berprestasi lebih dan bahkan mencarikan kesempatan bagi siswa secara adil. Hal ini sejalan dengan hasil wawancara dengan guru yang menunjukkan bahwa beberapa guru memang aktif dalam memberikan motivasi kepada siswa untuk berprestasi. Hasil juga menunjukkan beberapa guru sudah mampu melakukan komunikasi terbuka di mana mereka menanyakan pendapat siswa terlebih dahulu sebelum melakukan keputusan.

Berdasarkan dari pemahaman di atas, dapat disimpulkan bahwa gambaran dukungan sosial dari guru yang dirasakan oleh siswa SMA "X" cukup memuaskan bagi siswa tetapi masih dapat ditingkatkan lagi. Hal ini dikarenakan belum semua guru dianggap sudah bagus dalam memberikan dukungan sosial kepada siswa. Total guru yang berjumlah 17 orang untuk siswa sebanyak 67 orang seharusnya dapat ditingkatkan dalam kemampuan komunikasi sehingga mampu memberikan dukungan sosial kepada siswa dengan lebih baik lagi.

\section{DAFTAR PUSTAKA}

Cheon, S. H., \& Reeve, J. (2015). 'A classroom-based intervention to help teachers decrease students' amotivation', Contemporary Educational Psychology, vol 40, pp 99-111.

Debora, Y. (2016). Mendikbud: kualitas pendidikan ditentukan guru. Tirto.id. Tirto. Tanggal akses 8 Mei 2019.

Gutiérrez, M., Tomás, J. M., Romero, I., \& Barrica, J. M. (2017). 'Perceived social support, school engagement and satisfaction with school', Revista de Psicodidáctica, Vol. 22, no. 2, pp. 111-117.

Kozan, S., Fabio, A. D., Blustein, D. L., \& Kenny, M. E. (2013). 'The role of social support and workrelated factors on the school engagement of Italian high school students', Journal of Career Assessment, Vol 22 no. 2, pp. 1-10.

Wang, M. T., \& Eccles, J. S. (2012). 'Social support matters: Longitudinal effects of social support on three dimensions of school engagement from middle to high school', Child development, vol 83 no. 3, pp 877-895. 